\title{
Sağlık Bakanlığı Tarafından Yapılan Covid-19 Ek Ödemesi Hakkında Sağlık Personeli Görüşlerinin İncelenmesi
}

\author{
Investigation of Opinions of Health Staff About Covid-19 Additional Payment by the Ministry of Health
}

\author{
Özer Arık ${ }^{* 1}$ (D) Adil Aydoğdu 2 (D) \\ ${ }^{1}$ Master of Health Management, Selcuk University, Konya, Turkey \\ 2 Department of Health Management, Selcuk University, Konya, Turkey
}

Received: 23.08 .2021

Accepted: 28.09 .2021

This article was checked by intihal.net

Öz

Bu araştırma; COVID-19 pandemisi döneminde Sağlık Bakanlığı tarafından sağlık çalışanlarına yapılan ek ödeme teşvikinin sağlık personeli tarafından nasıl algılandığını ölçmek amacıyla yapılmıştır. Kesitsel tipteki bu araştırmada metod olarak niceliksel yöntem kullanılmıştır. Veri toplamak amacıyla araştırmacılar tarafından hazırlanmış sorulardan oluşan anket formu uygulanmıştır. Uygulanan anket, demografik sorular haricinde toplam 20 sorudan oluşmaktadır. Araştırmaya katılanların cinsiyet, yaş ve medeni durumları ile Covid-19 ek ödemesi hakkındaki düşünceleri arasında ki-kare analizi yapılmıştır. Covid-19 çalışması kapsamında Sağlık Bakanlığı izni ve diğer etik onaylar alınmıştır.

Çalışma sonucunda, Covid-19 ek ödemesinin bireysel performansı arttırması ile cinsiyet arasında anlamlı bir ilişki tespit edilmiştir ( $p$ $<0,05$ X2 = 11,423). Covid-19 ile mücadelede çalışma performansına göre beklentilerin altında ödeme yapılma durumu ile yaş arasında anlamlı bir ilişki tespit edilmiştir ( $p<0,05$ X2 = 19,588). Medeni durum ile Covid-19 mücadelesindeki çalışma performansına göre beklentilerin altında ek ödeme yapılma durumu arasında anlamlı bir ilişki tespit edilmiştir ( $p<0,05$ X2 =10,222). Kadın çalışanların Covid-19 ek ödemelerine erkeklere göre daha temkinli yaklaştıkları görülmüştür. Yaş azaldıkça ek ödeme beklentisinin arttığı görülmüştür. Bekâr çalışanların Covid-19 ek ödemelerinden beklentilerinin evli çalışanlardan fazla olduğu görülmüştür.

Anahtar Kelimeler: Covid-19 ile Mücadele; Sağlık Profesyonelleri; Ek Ödeme; Performans.

\section{Abstract}

This research was conducted to measure how healthcare professionals perceive the additional payment incentives provided by the Ministry of Health to healthcare workers during the COVID-19 pandemic. In this cross-sectional study, quantitative method was used. In order to collect data, online questionnaire form prepared by the researchers was applied to the hospital staff. The questionnaire consists of 20 questions in total, excluding demographic questions. A chi-square analysis was conducted between the gender, age and marital status of those included in the study and their thoughts about Covid-19 additional payment. Ministry of Health permission and other ethical approvals were obtained within the scope of the Covid- 19 study.

As a result of the study, a significant relationship was found between Covid-19 additional payment to increase individual performance and gender $(p<0.05 \times 2=11.423)$. According to the performance of the work in the fight against Covid-19, a significant relationship was found between the payment status below expectations and age $(p<0.05 \times 2=19.588)$. A significant correlation was found between marital status and additional payment below expectations based on the performance of work in the fight against Covid-19 ( $p<0.05 \times 2=10.222$ ). It has been observed that female employees are more cautious about Covid-19 additional payments than men. It was seen that the expectation of additional payment increased as the age decreased. In terms of marital status; It has been observed that the expectations of single employees from Covid19 additional payments are higher than that of married employees.

Keywords: Fight Against Covid-19; Healthcare Professionals; Additional Payment; Performance.

Arık, Ö. \& Aydoğdu, A. (2021). Sağlık Bakanlığı Tarafından Yapılan Covid-19 Ek Ödemesi Hakkında Sağlık Personeli Görüşlerinin İncelenmesi. Journal of Academic Value Studies, 7(2), 231-242. http://dx.doi.org/10.29228/javs.52433

\footnotetext{
*E-mail: ozerarik10@gmail.com (Corresponding Author)
} 


\section{Giriş}

Koronavirüs 2019 hastalığı (Covid-19), Aralık 2019'da Çin'in Wuhan kentinde ortaya çıktığı ilk günden bu yana tüm dünyada vaka ve ölüm sayıları hızla artmıştır. Covid-19 adıyla boy gösteren bu hastalık bireylerde, soğuk algınlığından şiddetli solunum yolu hastalıklarına; akciğer hastalıklarından ölüme kadar kişiden kişiye değişen ciddi sonuçlara neden olmaktadır (Rasmussen vd., 2020; Uysal vd., 2020). Dünya Sağılı Örgütü (DSÖ) tarafından bir pandemi olarak ilan edilen Covid-19 (WHO, 2020), uluslararası düzeyde önemi haiz bir halk sağlığı acil durumu olmaya (Choi vd., 2020) ve halen mutasyona uğrayan korona virüs endişesi ve aşılama çalışmaları ile gündemi meşgul etmeye devam etmektedir. DSÖ tarafından günlük olarak yayınlanan durum raporlarına göre hem vaka sayısı hem de virüs kaynaklı ölümler her geçen gün artmaktadır (WHO, 2021).

Tüm dünyada olduğu gibi Türkiye'de Covid-19 salgını ile mücadelede öncelikli olarak hastalığın yayılmasının önlenmesi hedeflenmiş, bunun yanında tüm sağılı hizmetleri hastalığın tanı ve tedavisine yönlendirilmiştir. Covid-19 hastalığının bireyleri sadece tıbbi ya da fiziksel değil, psikolojik olarak da ciddi şekilde etkilediği süreçte, covid-19 kaygısı nedeniyle uyku problemleri de dahil pek çok yeni rahatsızlık ortaya çıkmıştır (Kıraç vd., 2021). Iş̧te böylesi karmaşık bir ortamda sağlık çalışanları, normalde olduğunun birkaç katı efor sarf etmek durumunda kalmışlardır. Covid-19 hastalarının tanı ve tedavisinde ön saflarda yer alan sağlık çalışanları (Ali vd., 2020), enfekte olma ve ölüm riskinin çok yüksek olduğu koşullarda çalışmak zorunda kalmışlardır (Adams ve Walls, 2020). Bu bakımdan sağlık çalışanlarını korumak, Covid-19 salgını ile mücadelede halk sağlığı önlemlerinin önemli bir bileşeni haline gelmiştir (Lai vd., 2020). Salgınla mücadele eden doktor ve hemşirelerin de enfekte olduklarında karantinaya alındığı göz önüne alındığında Covid- 19'un, sağlık iş gücünün kullanılabilirliğini de etkilediği sonucu ortaya çıkmaktadır (Rajbhandari ve Maharjan, 2020).

Dünya çapında milyonlarca sağlık çalışanı, zor şartlarda Covid-19'lu hastalara bakım sağlamanın zorluğu içinde kendi hayatlarını riske atarak görev yapmaktadır. Bağlııkları, özverileri ve profesyonellikleri ile insanlığı onurlandırmaktadırlar (Bauchner and Easley, 2020). Aynı zamanda, Covid-19 hastalarına bakan sağlık personeli zihinsel stres, fiziksel tükenmişlik, ailelerinden ayrılma, damgalanma, hasta ve meslektaşlarını kaybetmenin acılarıyla karşı karşıyadır (Chersich vd., 2020).

Salgının başlangııından günümüze kadar geçen sürede sağlık çalışanları giderek daha fazla oranda enfekte olmaktadır (Türk Toraks Derneği, 2021). Bu nedenle, gerek kişisel koruyucu ekipman mevcudiyeti ve personelin hazır bulunması, gerekse çeşitli teşvikler ve psikolojik destek yoluyla sağlık çalışanlarının yetkili makamlarca korunmasına yönelik tedbirler önerilmektedir (Ali vd., 2020). Vaka/ölüm oranlarında her ne kadar dünyada alt sıralarda yer alsa da Türkiye'de her 74 Covid-19 hastasından birinin sağlık çalışanı olduğu düşünülmektedir (Uysal vd., 2020; Türk Toraks Derneği, 2021). Bu riskin yanında salgınla mücadelede artan yorgunluk, karar verme ve konsantrasyon güçlüğü yaşayan sağlık çalışanlarının \%77,6'sı pandemi döneminde iş yükünün arttığını ve $67,9^{\prime} u$ ise performans düşüklüğü yaşadığını belirtmiştir (Saatçı, 2020). Sağlık çalışanları her ne kadar seçtikleri mesleğin doğası gereği artan enfeksiyon riskini kabul etseler de, aile üyelerine (özellikle yaşı, bağışıklığı zayıflamış veya kronik hastalıkları olanlar) hastalığı bulaştırma konusunda endişe duymaktadır. Sağlık çalışanları için riskin tamamen ortadan kaldırıması mümkün olmamasına rağmen, ihtiyatlı düzenlemeler yapılarak desteklenebilmeleri mümkündür (Adams ve Walls, 2020).

Sağlık profesyonelleri, içinde bulunulan salgın döneminde çalıştıkları sağıı kuruluşlarının kendilerine ve ailelerine destek olacağına dair kesin bir güvence aramaktadırlar. Çalışıkları kuruluşların kaygılarını dikkate alarak, Covid-19 hastalığına yakalanmalarını önlemek için mümkün olan her şeyi yapacaklarından ve enfekte olmaları durumunda kuruluşlarının kendilerini ve ailelerini tıbbi ve sosyal yönden destekleyeceklerinden emin olmak istemektedir (Shanafelt vd., 2020). Sağlık çalışanları pandemi döneminde uzun ve stresli mesailer yapmak zorunda kalmışlardır. Bu zorlu mesai şartları aile ilişkilerine de yansımıştır. Özellikle çocuklu sağlık çalışanlarında eğitim kurumlarının kapanması ile birlikte çocuklarının bakım sorunu ve yaşlı ebeveynlerinden uzakta kalma problemleri ile karşı karşıya gelmişlerdir.

Diğer yandan salgın, hastaneler ve sağlık çalışanları tarafından ciddi finansal sonuçları da beraberinde getirerek, sağlık çalışanlarının içinde bulundukları bu zor dönemde mali sıkıntılarla karşı karşıya kalmalarına yol açmıştır (Farooq ve Ali, 2020). Örneğin, İrlanda'da yapılan bir çalışmada araştırmaya katılan hekimlerin \%76'sının \%70'in üzerinde gelir kaybı bekledikleri ortaya konmuştur (IDA, 2021). Tüm bunlar Covid-19'a maruz kalan sağlık çalışanlarında zihinsel iyiliği teşvik etmek ve içinde bulunulan bu ortamda çalışanların motivasyonlarını artırmak için özel müdahalelerin acil bir şekilde uygulanmasını gerektirmiştir (Lai vd., 2020; Rajbhandari ve Maharjan, 2020). 
Sağ|ıkta kalitenin arttırıması için sağlık çalışanlarının her yönden motive edilmesi önem arz etmektedir (Yorulmaz ve Uysal, 2019). Tüm bunlardan yola çıkarak, sağlık personelinin en iyi şekilde motive edilerek adil bir performans değerlemesinin yapılacağı ücretlendirme sistemleri gerekmektedir. Türkiye'de Sağlık Bakanlığınca 2004 yıından itibaren performansa göre döner sermaye katkı payı ödemesi sistemi uygulanmaktadır (Sağlık Bakanlığı [SB], 2007). Bu performans sistemi, günümüze kadar birçok yeni ve ulusal standartları içeren düzenlemeler yapılarak Sağlık Bakanlığı tarafından geliştirilmiştir. Kamu hastanelerinde performansa dayalı ek ödeme sistemi, hekim, hemşire gibi sağlık çalışanlarına ikramiye vermeyi amaçlamaktadır. Bu prim ödemesi performansı artırmak, sağlık personeli arasında iş motivasyonunu ve üretkenliği teşvik etmek amacıyla, kayıtlara dayalı olarak nitelikli sağlık hizmeti üreten profesyonellere tüm kurumun değerlendirmesi ile verilmektedir (Kaptanoglu, 2013). Sistem, parasal bir ödeme modeli olmaktan öte başarı kriterlerine göre çalışanı ödüllendirerek bireysel açıdan verimliliğin arttııımasını, getirilen performans ölçütleri sayesinde ise kurumsal etkinliği sağlayan bir uygulamadır (SB, 2007).

Olumlu yönlerinin yanı sıra dengeli ve adil bir ücret yapısı kurulmayan ödeme sistemleri ise, hem işveren hem de personel açısından bir takım sorunları da beraberinde getirmektedir. Bu konuda çalışanların en önemli rahatsızığı, düşük ücret almaktan ziyade, kendileri ile aynı işi yapan kişilerden daha düşük ücret almaları olmaktadır. Bu yüzden bu problemin çözülmesinde eşit işe eşit ücret prensibine bağlı kalmak önem arz etmektedir (Erkan, 2011). Performansa dayalı ek ödeme sistemi, bilimsel açıdan bir performans değerlendirmesi sağlayamadığı şeklinde (Yüksel ve Sayın, 2018), çeşitli eleştirilere maruz kalsa da, kaynakların optimum kullanılmasını sağlaması ve sağlık çalışanları için ek bir gelir yaratması bakımından büyük önem taşımaktadır. Döner sermaye gelirlerinin elde edilmesinde doğrudan katkı payı sahibi olan sağılık çalışanlarının, aynı zamanda bu gelirlerin dağııımında alınacak yönetimsel kararlarda da söz sahibi olmasına imkân tanınması, iş barışı için son derece önemlidir (Çakır ve Sakaoğlu, 2014).

Salgın dönemlerinde hastane ve sağlık çalışanlarının acil ihtiyaçlarını karşılamaları için yapılacak parasal destekler, çalışma performansının maksimizasyonu için en az yeterli sayıda kişisel koruyucu ekipman temin etmek ve psikolojik destek sağlamak kadar önemlidir. Çünkü sağlık çalışanlarının güçlü bir motivasyonla görev yapabilmesi için salgının neden olduğu maddi sorunlar yüzünden ailesi ve geleceği için endişe duymaması, tüm dikkati ve enerjisiyle hastalıkla mücadeleye odaklanması gerekmektedir. Bu bakımdan, salgınla mücadelenin lokomotif gücü olan sağlık personelinin motive edilerek çalışma performansının artıııması, psikolojik desteğin yanı sıra, maddi olarak da iyileştirmelerin yapılması bu sürecin en az kayıpla atlatılması için oldukça önemli görülmektedir.

Şu açıktır ki, pandemi ile savaşta kilit rol oynayan sağlık çalışanları bu hassas dönemde özveriyle görev yapmıştır. Bu nedenle sağlık çalışanlarının herhangi bir maddi kayba uğramalarının önlenmesi, motive ve teşvik edilmesi amacıyla, 24/03/2020 tarihli ve 31078 sayılı Resmi Gazete ile gerek Sağlık Bakanlığı'na bağlı sağık tesislerinde ve gerekse üniversite hastanelerinde görevli personele, 01/03/2020 tarihinden itibaren geçerli olmak üzere üç ay süreyle ek ödeme yapılmasına karar verilmiştir (SB, 2007; Resmi Gazete, 2020).

Verilen kararlar ve uygulanan yöntemler konusunda yürürlükteki performans uygulamasının, sahadaki sağılı hizmetlerine ve özellikle salgınla mücadele sürecine olumlu ve olumsuz yansımalarının neler olduğunun tespit edilmesi, bundan sonraki dönemlerde yapılacak benzer uygulamalara ışık tutması bakımından çok önemlidir. Yapılan literatür taramasında, Covid-19 ile mücadele kapsamında görev yapan sağlık personelinin hastalıkla enfekte olmasının engellenmesi için kişisel ve koruyucu ekipman kullanımının ve gerekli malzeme tedariğinin sağlanması, sağlık çalışanlarının bu süreçte psikolojik ve davranışsal yönden desteklenerek motive edilmesi gibi konularda çalışmaların yapıldığı görülürken (Di Tella vd., 2020; Vizheh vd., 2020; Greenberg vd., 2020; Tomlin vd., 2020; Park, 2020; Zhao vd., 2020; Livingston vd., 2020), sağlık çalışanlarının salgınla mücadele sürecinde maddi açıdan desteklenerek performanslarının artııılmasına yönelik herhangi bir çalışmaya rastlanmadığı görülmüştür.

Bu çalışmada, ülkemizde Covid-19 pandemisi ile mücadele kapsamında Sağlık Bakanlığı tarafından sağlık çalışanlarına yapılan Covid-19 ek ödemesinin sağlık profesyonelleri tarafından nasıl algılandığının ölçülmesi amaçlanmıştır. Diğer bir amaç ise, bu ücret teşviki hakkında sağlık çalışanlarının fikirlerini almak, konu ile ilgili yapılacak araştırmalara ve olası yasal düzenlemelere yol gösterici fikirler sunmaktır.

\section{Gereç ve Yöntem}

\subsection{Araştırmanın Türü}

Tanımlayıcı türde, kesitsel tipteki bu araştırmada metod olarak niceliksel yöntemlerden anket yöntemi kullanılmıştır. 


\subsection{Araştırmanın Yapıldığı Yer}

Araştırmanın yapıldığı yer, Konya ilinde yer alan bölgesel nitelikte üçüncü basamak düzeyde sağlık hizmeti sunan ve 1350 yataklı bir üniversite hastanesidir. Aynı zamanda Covid-19 salgını ile mücadelede uzman sağlık iş gücü ile etkin bir rol oynayan Konya'daki pandemi hastanelerinden biridir.

\subsection{Veri Toplama Aracı ve Analiz Yöntemi}

Araştırmanın amacı doğrultusunda, katılımcıların düşüncelerini öğrenebilmek amacıyla literatürden (SB, 2007; Fettah ve Şahin, 2009; Gazi vd., 2011; Çakır ve Sakaoğlu, 2014; Kablay, 2014; Yüksel ve Sayın, 2018; Resmi Gazete, 2020) yararlanılarak bir online anket formu oluşturulmuştur. Anket, kişisel bilgi formu kapsamında bireylerin cinsiyeti, yaşı, medeni durumu, eğitim durumu ve gelir durumu gibi demografik sorular haricinde araştırmacılar tarafından hazırlanan toplam 20 sorudan oluşmaktadır. Anket, 3'lü Likert tarzda oluşturulmuştur. Değerlendirme, 1="Katılmıyorum", 2="Kararsızım", 3="Katıııorum" şeklindedir. Online anket formu, çevrimiçi veri toplama yöntemlerinden Google Formlar aracıllğıyla çalışanlara uygulanarak veriler toplanmıştır. Toplanan verilerin düzenleme işlemi Microsoft Excel 2019 programında yapıldıktan sonra, veriler SPSS 26.0 paket programı kullanılarak istatistiksel olarak analiz edilmiştir.

\subsection{Evren ve Örneklem}

Anket formu yetişkin bireyler üzerine uygulanmış olup, araştırmanın evreni çalışmanın yapıldığı hastanede görev yapan ve Covid-19 nedeniyle ek ödeme alan sağlık çalışanlarından oluşmaktadır. Bu itibarla çalışma evreni olarak, araştırmanın yapıldığı hastaneden edinilen bilgiye göre en son dönemde ek ödeme alan sağılı çalışanı sayısı (2067 kişi) temel alınmıştır. Yansızıı (random) kuralına göre evreni temsil edecek örneklem büyüklüğü 0.03 örnekleme hatası ile 748 olarak hesaplanmıştır. Anket çalışmasında tüm evrene ulaşılmaya çalışılmış, toplam 990 yanıt alınmıştır. Eksik ve mükerrer cevaplar gibi hatalı veriler ayıklandıktan sonra 969 anket formu değerlendirmeye alınmış, araştırma örneklemine 969 sağlık çalışanı dâhil edilmiştir.

\subsection{Araştırmanın Etik ve İzin Boyutu}

Öncelikle, çalışma ile ilgili bilimsel araştırma başvurusu yapılarak Sağlık Bakanlığı'ndan onay alınmıştır. Akabinde, Selçuk Üniversitesi Sağılı Bilimleri Fakültesi Girişimsel Olmayan Klinik Araştırmalar Etik Kurulu'ndan 24.06.2020 tarih ve 2020/06 sayılı etik kurul izni alınmıştır. Araştırmanın yapılacağı üniversite hastanesinden de gerekli idari izinler alındıktan sonra katılımcıların onayı ile anket formu uygulanmıştır.

\subsection{Araştırmanın Sınırıııkları}

Çalışmada ulaşılan bulgular, araştırmanın yapıldığı üniversite hastanesinde görev yapan sağıık çalışanları ile sınırıdır. Bu nedenle araştırmadan elde edilen sonuçlar, tüm sağlık kurumları ve sağlık personelleri için genellenemez.

\section{Bulgular ve Tartışma}

Araştırma sonucunda elde edilen bulgular aşağıda sıralanmıştır.

Tablo 1. Katılımcılara Ait Demografik Veriler

\begin{tabular}{lcc}
\hline Cinsiyet & $\mathrm{n}$ & $\%$ \\
\hline Erkek & 196 & 20.2 \\
Kadın & 773 & 79.8 \\
\hline Yaş & $\mathrm{n}$ & $\%$ \\
\hline $20-30$ & 141 & 14.8 \\
$31-40$ & 264 & 27.2 \\
$41-50$ & 564 & 58.2 \\
\hline Medeni Durum & $\mathrm{n}$ & $\%$ \\
\hline Evli & 807 & 83.3 \\
Bekâr & 162 & 16.7 \\
\hline Gelir Durumu & $\mathrm{n}$ & $\%$ \\
\hline $2501-4000$ & 178 & 18.4 \\
$4001-5500$ & 858 & 67.9
\end{tabular}




\begin{tabular}{lrc}
$5501-7000$ & 109 & 11.2 \\
$7001-+$ & 24 & 2.5 \\
\hline Öğrenim durumu & $\mathrm{n}$ & $\%$ \\
\hline Lise & 51 & 5.3 \\
Ön lisans & 543 & 56 \\
Lisans & 341 & 35.2 \\
Lisansüstü & 34 & 3.5 \\
\hline
\end{tabular}

$\mathrm{n}=969$

Tablo 2. Covid-19 Ek Ödemesinin Değerlendirilmesine İlişkin Tanımlayıcı İstatistikler

\begin{tabular}{llllllllll}
\hline & $n$ & $\%$ & $n$ & $\%$ & $n$
\end{tabular}

1. Covid-19 ek ödemesi, sağlık hizmetlerinde kalite ve verimliliği artırmıştır.

2. Covid-19 ek ödemesi, bireysel performansımın artmasını sağlamıştır.

$\begin{array}{rrrrrr}677 & 69.9 & 93 & 9.6 & 199 & 20.5 \\ 689 & 71.1 & 78 & 8 & 202 & 20.8\end{array}$

3. Covid-19 ek ödemesi, iş hayatında moral ve motivasyon seviyemi yükseltmiştir.

4. Covid-19 ek ödemesi, herhangi bir maddi kayba uğramamı önlemiştir.

$\begin{array}{lllll}633 & 65.3 & 92 & 9.5 & 244\end{array}$

$\begin{array}{llllll}565 & 58.3 & 111 & 11.5 & 293 & 30.2\end{array}$

5. Covid-19 ek ödemesi, tüm sağlık personelini kapsayan adil bir düzenleme olmuştur.

6. Covid-19 ek ödemesi, genel olarak hekimler dikkate alınarak yapılmış bir düzenlemedir.

7. Covid-19 ile mücadeledeki çalışma performansıma göre beklentimin altında bir ödeme yapıldı.

8. Covid-19 hastaları ile birebir temaslı çalışan sağlık personelinin, diğer alanlarda çalışan personelden daha fazla ek ödeme alması gerektiğini düşünüyorum.

$\begin{array}{rrrrrr}875 & 90.3 & 34 & 3.5 & 60 & 6.2 \\ 64 & 6.6 & 53 & 5.5 & 852 & 87.9 \\ 139 & 14.3 & 93 & 9.6 & 737 & 76.1 \\ 122 & 12.6 & 43 & 4.4 & 804 & 83 \\ & & & & & \\ 554 & 57.2 & 176 & 18.2 & 239 & 24.7 \\ 47 & 4.9 & 25 & 2.6 & 897 & 92.6 \\ 145 & 15 & 115 & 11.9 & 709 & 73.2\end{array}$

9. Covid-19 ek ödemesi yapan diğer hastanelerde çalışan sağlık personeli ile aynı oranda ek ödeme aldığımı düşünüyorum.

10. Covid-19 ek ödemesinin, hastanede sürekli işçi kadrosunda görev yapan (temizlikçi, hastabakıcı, sekreter, güvenlik, garson vb.) sağlık çalışanlarını da kapsaması gerektiğini düşünüyorum.

11. Sürekli iş̧̧i kadrosunda görev yapan personele Covid-19 ek ödemesi yapılmaması çalışma barışımızı bozmuştur.

12. Çalıştığım hastanede Covid-19 ek ödemesinin dağıtım kriterleri belirlenirken hakkaniyete uygun davranılmıştır.

13. Çalıştığım hastanede Covid-19 ek ödemesi yapılırken, sağıık personelinin görev yaptığı birim ve personele bulaş riski dikkate alınmıştır.

$\begin{array}{rrrrrr}782 & 80.7 & 107 & 11 & 90 & 8.3 \\ 648 & 66.6 & 144 & 14.9 & 177 & 18.3 \\ 917 & 94.6 & 20 & 2.1 & 32 & 3.3\end{array}$

kriterleri belirlenirken, benim de fikir ve görüşlerim alınmıştır.

15. Çalıştığım hastanede Covid-19 ek ödemesi ile ilgili alınan yönetimsel kararlara katılım sağlamama imkân verilmiştir. 
16. Covid-19 ek ödeme oranlarının daha yüksek belirlendiği başka bir hastanede görev yapmayı tercih ederdim.

17. Covid-19 ile mücadeleyi teşvik etmek için böyle bir ücretlendirmenin gerekli olduğunu düşünmüyorum.

$\begin{array}{llllll}358 & 36.9 & 256 & 26.4 & 355 & 36.6\end{array}$

18. Covid-19 ek ödemesi yerine, özlük haklarımın iyileştirilmesini tercih

$\begin{array}{llllll}547 & 56.4 & 117 & 12.1 & 305 & 31.5\end{array}$

19. Covid-19 ek ödemesini, salgınla mücadeleyi para

karşılığı hizmet sunumuna indirgediği için doğru

bulmuyorum.

$\begin{array}{lllll}6.6 & 40 & 4.1 & 865 & 89.3\end{array}$

20. Covid-19 ek ödeme süreci, hastane yönetimince iyi yönetilmiştir.

48.5

$\mathrm{n}=969$

Covid-19 ek ödemesinin genel olarak değerlendirildiği sonuçların yer aldığı Tablo 2'de kurumda araştırmaya katılmayı kabul eden sağlık çalışanlarının sorulara verdikleri yanıtların dağııımı yer almaktadır. Tablo 2'de yer alan bulgulara göre, katııımcıların "katılmıyorum" seçeneğini en fazla işaretledikleri madde "14. Çalıştığım hastanede Covid-19 ek ödemesinin dağıtım kriterleri belirlenirken, benim de fikir ve görüşlerim alınmıştır." maddesi iken; 'katılıyorum' seçeneğini en fazla işaretledikleri maddenin "10. Covid-19 ek ödemesinin, hastanede sürekli iş̧̧i kadrosunda görev yapan (temizlikçi, hastabakıcı, sekreter, güvenlik, garson vb.) sağlık çalışanlarını da kapsaması gerektiğini düşünüyorum." olduğu görülmüştür (Tablo 2).

Bölgesel nitelikte üçüncü basamak sağlık hizmeti sunan bir kamu hastanesinde yapılan yukarıdaki araştırma bulgularına göre, Covid-19 ek ödemesinin kapsam ve oranının nasıl belirleneceği, dağıtım kriterlerinin neler olması gerektiği hakkında çalışanların görüş ve fikirlerinin yeterince alınmaması nedeniyle demokratik bir katılımın sağlanamadığı düşünülmektedir. Doğal olarak sağlık çalışanları, emeklerinin karşılığı olan döner sermaye gelirlerinin elde edilmesinde katkı sahibi olduğu kadar, aynı zamanda dağıtımında ve alınacak yönetimsel kararlarda da söz sahibi olmak istemektedir. Sonuç olarak, Covid-19 ek ödemesi ile ilgili sürecin yönetimine sağlık çalışanlarının da dâhil edilmesi konusunda üst yönetim desteğinin sınırlı olduğu düşünülmektedir.

Çakır ve Sakaoğlu'nun (2014) yaptığı bir araştırmada, sağlık çalışanlarının aslında performansa dayalı ek ödemeye karşı olmadıkları, ancak sistemin adil bir ücretlendirmeye dayalı olması talebiyle yapısal değişiklikler beklentisi içinde oldukları tespit edilmiştir. Araştırmamıza dâhil olan katılımcılar da benzer şekilde, Covid-19 ek ödemesini sağlık çalışanlarının tümünü kapsayan adil bir düzenleme olarak kabul etmemektedir. Buna göre sağlık çalışanları, yapılan yasal düzenlemenin farkı sınıf ve kadrolarda görev yapan sağlık meslek grupları düzeyinde ya da yaptıkları işin niteliği veya miktarı oranında hak ettikleri ek ödemeyi alamadıklarını düşünmektedir. Bununla birlikte, hastane yönetiminin de Covid-19 ek ödemesinin dağıtım kriterlerini belirlerken bu durumu dikkate almayarak hakkaniyete uygun davranmadığı anlaşımaktadır. Sonuç olarak, ek ödeme sürecine ilişkin sağlık çalışanlarının yönetime olan güven duygusunun tatmin edici olmadığı düşünülmektedir.

Sağlık personelinin özlük haklarının yapılacak yasal düzenlemelerle döner sermaye yerine, hastane bütçesinden karşılanabileceğini düşünen Taser ve Cakır (2019), sadece hacme dayalı çalışanın değil, verimli ve kaliteli hizmet üreten çalışanın ödüllendirileceği bir ek ödeme sistemi önerisinde bulunmaktadır. Araştırmaya katılan sağlık çalışanları da Covid-19 ek ödemesinin sağıık hizmetlerinde kalite ve verimliliği artırdığını düşünmemektedir. Çünkü performansa dayalı ücretlendirmenin esası genel olarak sayıya veya hacme dayalı bir ödeme sistemini tanımlamaktadır. Söz konusu bulgu, sağlık hizmetlerinde kalite ve verimliliğin para ile ödüllendirme dışında, sağlık çalışanlarının Covid-19 ile mücadelede sergiledikleri performansın zaten mesleklerinin bir gereği olduğu inancıyla da ilişkili olabileceğini düşündürmektedir.

Covid-19 ek ödemesi için yapılan yasal düzenleme gereği hastanede görev yapan hekimler, memurlar ve sözleşmeli personel ödeme alabilirken, yardımcı sağlık hizmetlerini yürüten sürekli işçi kadrosundaki temizlikçi, hastabakıcı, sekreter, güvenlik, aşçı vb. sağlık çalışanları bu ödemeden faydalanamamıştır. Araştırma bulgularına göre, katıımcıların büyük bir kısmı (\%92.6) sürekli işçi kadrosunda görev yapan sağlık çalışanlarının ayrım gözetmeksizin ek ödeme alması gerektiğini düşünmektedir. Bu bulgu, sağlık hizmetlerinin bütüncül bir yaklaşımla 
ve ekip anlayışı içinde sunulmasının doğası gereği, iş sağlığı ve güvenliği açısından çok tehlikeli işyeri sınıfında yer alan hastanelerde aynı klinikte aynı bulaş riskini taşıyan sağlık çalışanlarının tamamının ek ödeme uygulamasından yararlanması gerektiği sonucunu ortaya çıkarmaktadır.

Diğer bir bulguya göre, katılımcıların \%66.6'sı Covid-19 ek ödemesi yapılırken, sağılık personelinin görev yaptığı birim ve personele bulaş riskinin dikkate alınmadığını düşünmektedir. Öte yandan, katıımcıların \%83'ü Covid-19 hastaları ile birebir temaslı çalışan sağlık personelinin, diğer alanlarda çalışan personelden daha fazla ek ödeme alması gerektiğini düşünmektedir. Bir başka deyişle, daha fazla risk alanların daha fazla pay almasını, yani çalışma barışı açııından adil olunması gerektiğini savunmaktadır. Kablay (2014) tarafından yapılan bir araştırma sonucuna göre performansa dayalı ek ödeme sistemi, sağlık personeli açısından gelir arttırıcı bir uygulama olarak kabul edilse de, aynı birimde görev yapanlar arasında getirdiği rekabet anlayışı nedeniyle çalışma barışını bozan bir etkisinin olduğu saptanmıştır. Araştırmada elde edilen bulgulara göre, katıımcıların büyük bir kısmı (\%73.2) sürekli iş̧̧i kadrosunda görev yapan personele Covid-19 ek ödemesi yapılmamasının çalışma barışını bozacağı endişesini taşımaktadır.

Araştırmaya katılan sağlık çalışanlarının \%87.9'u Covid-19 ek ödemesinin genel olarak hekimler dikkate alınarak yapılmış bir düzenleme olduğu konusunda görüş bildirmişlerdir. Ortaya çıkan bu sonucun, hekimlerin ek ödeme pastasının en büyük dilimini almalarından kaynaklandığı düşünülmektedir. Performansa dayalı ek ödeme, ilgili mevzuat çerçevesinde daha çok tıbbi işlemlerin puanlandıııması esasına dayandığından, doğal olarak hekimlerin aldığı ek ödeme payı büyüktür (Yüksel ve Sayın, 2018). Çünkü bu sistem, genel olarak hekimlere yaptığı iş oranında hak ettiği kadar, diğer sağlık çalışanlarına ise hastanenin genel performans puanına göre döner sermaye ödendiği bir sistemdir (Gazi vd., 2011). Burada dikkat edilmesi gereken durum, ek ödeme dağıtımı konusunda ortaya çıkabilecek adaletsizliklere karşı dikkatli olmayı gerektirmektedir. Ayrıca, katılımcıların \%76.1'i Covid-19 ile mücadelede gösterdiği performansa karşııık gelen emeğinin altında bir ödeme yapıldığını düşünmektedir. Bu bulguya göre, sağık çalışanlarının Covid-19 ek ödemesinin beklenen motivasyonu sağlamasında tatmin edici bir etki oluşturmadığı düşünülmektedir.

Fettah ve Şahin (2009) tarafından yapılan bir başka araştırmada elde edilen sonuçlara göre, ek ödeme sisteminin ekonomik fayda sağladığı ancak, maaşlarda iyileştirme yapılması konusunu gündem dışında bıraktığı söz konusudur. Araştırmamızda katılımcıların \%89.3'ü Covid-19 ek ödemesi yerine, özlük haklarının iyileştirilmesini tercih etmektedir. Bulguya göre aslında sağlık çalışanları, hizmette kalite ve verimliliğin artırııması için özlük haklarının iyileştirilmesini, performansa dayalı ek ödemeye tercih etmektedir.

Araştırmaya katılan sağlık çalışanlarının \%63.2'si, Covid-19 ek ödeme sürecinin hastane yönetimince iyi yönetilmediğini düşünmektedir. Buna karşılık, Covid-19 ek ödeme oranlarının daha yüksek belirlendiği başka bir hastanede görev yapmayı tercih etme konusunda kararsız kaldıkları görülmektedir. Bulgulara göre, sağlık çalışanları hastane yönetiminin Covid-19 ek ödemesi ile ilgili gösterdiği yönetim yaklaşımını benimsemese de kurumsal anlamda örgütsel bağlılıklarının yüksek olduğu düşünülmektedir.

Tablo 3. Covid-19 Ek Ödemesi Sistemini Değerlendirme Durumları ile Demografik Değişkenler Arasında Yapılan KiKare Analizi

\begin{tabular}{lllllll} 
& $\mathrm{X} 2$ & $p$ & $\mathrm{X} 2$ & $\boldsymbol{P}$ & $\mathrm{X} 2$ & $\boldsymbol{p}$ \\
\hline 1. Covid-19 ek ödemesi, sağ|ık hizmetlerinde kalite & 4.958 & 0.084 & 1.340 & 0.855 & 1.235 & 0.539
\end{tabular}

ve verimliliği artırmıştır.

2. Covid-19 ek ödemesi, bireysel performansımın artmasını sağlamıştır.

$\begin{array}{llllll}11.423 & 0.003 * & 1.734 & 0.785 & 2.845 & 0.241\end{array}$

3. Covid-19 ek ödemesi, iş hayatında moral ve motivasyon seviyemi yükseltmiştir.

$\begin{array}{llllll}1.397 & 0.497 & 0.805 & 0.938 & 4.135 & 0.127\end{array}$

4. Covid-19 ek ödemesi, herhangi bir maddi kayba uğramamı önlemiştir.

$\begin{array}{llllll}0.378 & 0.828 & 3.235 & 0519 & 2.510 & 0.285\end{array}$

5. Covid-19 ek ödemesi, tüm sağlık personelini

kapsayan adil bir düzenleme olmuştur.

$\begin{array}{llllll}4.291 & 0.117 & 4.898 & 0.298 & 3.999 & 0.135\end{array}$


6. Covid-19 ek ödemesi, genel olarak hekimler dikkate alınarak yapılmış bir düzenlemedir.

7. Covid-19 ile mücadeledeki çalışma performansıma göre beklentimin altında bir ödeme yapıldı.

$\begin{array}{lllllll}1.939 & 0.379 & 2.807 & 0.591 & 2.266 & 0.322 \\ 4.668 & 0.097 & 19.588 & 0.001 * & 10.222 & 0.006^{*} \\ & & & & & \\ & & & & & \\ 0.910 & 0.634 & 15.190 & 0.004^{*} & 3.740 & 0.154 \\ & & & & & \\ 2.161 & 0.339 & 6.793 & 0.147 & 10.879 & 0.004^{*}\end{array}$

8. Covid-19 hastaları ile birebir temaslı çalışan sağlık personelinin, diğer alanlarda çalışan personelden daha fazla ek ödeme alması gerektiğini düşünüyorum.

$\begin{array}{llllll}2.161 & 0.339 & 6.793 & 0.147 & 10.879 & 0.004^{*}\end{array}$
çalışan sağlık personeli ile aynı oranda ek ödeme aldığımı düşünüyorum.

10. Covid-19 ek ödemesinin, hastanede sürekli işçi kadrosunda görev yapan (temizlikçi, hastabakıcı, sekreter, güvenlik, garson vb.) sağlık çalışanlarını da kapsaması gerektiğini düşünüyorum.

$\begin{array}{llllll}0.256 & 0.880 & 9.455 & 0.051 & 5.448 & 0.066 \\ 0.430 & 0.806 & 4.733 & 0.316 & 0.739 & 0.691\end{array}$

Covid-19 ek ödemesi yapılmaması çalışma barışımız bozmuştur.

12.Çalışığım hastanede Covid-19 ek ödemesinin dağıtım kriterleri belirlenirken hakkaniyete uygun davranılmıştır.

$0.291 \quad 0.865 \quad 10.524 \quad 0.032 * \quad 3.317 \quad 0.190$

13. Çalıştığım hastanede Covid-19 ek ödemesi yapılırken, sağlık personelinin görev yaptığı birim ve personele bulaş riski dikkate alınmıştır.

$\begin{array}{llllll}0.296 & 0.861 & 3.155 & 0.215 & 4652 & 0.098\end{array}$

14.Çalıştığım hastanede Covid-19 ek ödemesinin dağıtım kriterleri belirlenirken, benim de fikir ve görüşlerim alınmıştır.

15. Çalıştığım hastanede Covid-19 ek ödemesi ile ilgili alınan yönetimsel kararlara katılım sağlamama imkân verilmiştir.

16.Covid-19 ek ödeme oranlarının daha yüksek belirlendiği başka bir hastanede görev yapmayı tercih ederdim.

17. Covid-19 ile mücadeleyi teşvik etmek için böyle bir ücretlendirmenin gerekli olduğunu düşünmüyorum.

18. Covid-19 ek ödemesi yerine, özlük haklarımın iyileştirilmesini tercih ederdim.

19. Covid-19 ek ödemesini, salgınla mücadeleyi para karşılığı hizmet sunumuna indirgediği için doğru bulmuyorum.

$\begin{array}{llllll}5.399 & 0.067 & 2.235 & 0.693 & 4.508 & 0.105\end{array}$

$\begin{array}{llllll}3.093 & 0.213 & 3.399 & 0.493 & 1.235 & 0.539\end{array}$

$11.804 \quad 0.003 * 35.899 \quad 0.000 * 16.7170 .000 *$

20. Covid-19 ek ödeme süreci, hastane yönetimince iyi yönetilmiştir.

$\begin{array}{cccccc}7.243 & 0.027 * & 16.664 & 0.002 * & 7.552 & 0.023 * \\ 2.581 & 0.275 & 29.659 & 0.000 * & 4.701 & 0.095 \\ & & & & & \\ 7.111 & 0.029 * & 30.303 & 0.000 * & 4.172 & 0.124\end{array}$

$\begin{array}{llllll}5.938 & 0.051 & 3.630 & 0.458 & 2.945 & 0.229\end{array}$ 
Araştırmaya dâhil olanların cinsiyeti, yaşı ve medeni durumu ile Covid-19 ek ödemesi hakkında düşüncelerine ait ki-kare analizi yapılmıştır. Katııımıların demografik özellikleriyle sorulara verdikleri yanıtlar arasında yapılan ki-kare testi sonuçları Tablo 3'te özetlenmiştir.

Yapılan ki-kare testi sonuçları katılımcı cinsiyetleri açısından incelendiğinde kadınların Covid-19 ek ödemesinin bireysel performansı arttırdığına yönelik algılarının erkeklere göre daha olumsuz olduğu, Covid-19 ödemelerinin daha yüksek belirlendiği başka kurumları tercih etme oranlarının erkeklerde kadınlara göre daha yüksek olduğu ve aynı zamanda erkeklerin ek ödemenin gerekliliğini daha fazla savundukları görülmüştür. Anket formunda yer alan başka bir maddede ise Covid- 19 ek ödemesini, salgınla mücadeleyi para karşılığı hizmet sunumuna indirgediği için doğru bulmama durumları irdelenmiş ve kadınların Covid-19 ek ödemelerini doğru bulmama oranlarının daha yüksek olduğu görülmüştür. Bu bağlamda, cinsiyet ile sorular arasında yapılan ki-kare sonuçları birlikte incelendiğinde, sonuçlar arasında tutarlıık olduğu ve kadınların Covid- 19 ek ödemelerine erkeklere göre daha temkinli yaklaştıkları görülmüştür.

Katılımcıların yaşları ile sorulara verdikleri cevaplar arasında yapılan ki-kare testi sonuçlarına göre yaş azaldıkça ek ödeme beklentisinin arttığı görülmüştür. Katılımcıların adil düşünme durumlarını ölçmek için sorulan soruya verilen cevaplar analiz edildiğinde ise yaş azaldıkça ek ödemenin dağııımında risk oranının dikkate alınması gerektiğini düşünenler artmaktadır. Yani gençlerde "ne kadar risk; o kadar ek ödeme" anlayışı hâkimdir. Covid-19 ek ödemelerinin dağııımında hakkaniyete uyulup uyulmadığının sorulduğu soruya hakkaniyete uyulmadığını belirtenlerin oranı yaş azaldıkça artmıştır. Ayrıca, yaş arttıkça Covid-19 ek ödemelerinin daha adil dağıııldığı bir hastanede çalışıyor olmayı isteme durumunun azaldığı, dolayısıyla gençlerin farklı hastanelerde olmayı daha fazla istedikleri görülmüştür. Başka bir sonuçta ise yaş azaldıkça, Covid-19 ile mücadelede böyle bir ek ödemenin gerekli olduğu düşüncesi artmıştır. Buna karşılık, Covid-19 ek ödemeleri yerine özlük haklarının iyileştirilmesi gerektiğini düşünenlerin oranının yaş arttıkça arttığı tespit edilmiştir. Tüm bunları destekleyici bir diğer sonuç ise yaş arttıkça Covid-19 ek ödemesinin para karşılı̆̆ hizmete indirgenemeyeceği düşüncesinin de artmasıdır. Bu bulgu, gençlerin salgınla mücadele olsa bile bunun maddi bir karşıı̆ıının olması gerektiği, olgunlaşan sağlık çalışanlarının ise salgınla mücadelenin mesleklerinin gereği olan kutsal bir görev olduğu bilinciyle parayla kıyaslanamayacağı kanısında olduklarını düşündürmüştür. Bir başka ifade ile yaş arttıkça, sergilenen mücadelenin Covid-19 ek ödemesinin bir sonucu olduğu kabul edilmemektedir. Bu sonuçlara göre yaş arttıkça çalışanların ek ödeme gibi geçici ve yüzeysel çözümler yerine, özlük haklarının iyileştirilmesi gibi daha kalıcı çözümlerin uygulanması gerektiğini düşünenlerin oranı artmıştır.

Tablo 3'e göre çalışanların medeni durumlarının sorulara verdikleri yanıtlar üzerindeki etkileri de araştırılmıştır. Yapılan analiz sonucunda, bekâr çalışanların Covid- 19 ek ödemelerinden beklentilerinin evli çalışanlardan fazla olduğu görülmüştür. Bunun yanında, evli çalışanların diğer hastanelerde çalışanlarla benzer şartlarda olduklarına yönelik görüş bildirme oranlarının daha fazla olduğu tespit edilmiştir. Ayrıca, bekârların Covid-19 ödemelerinin daha fazla yapıldığı başka hastanede çalışmayı tercih etme durumlarının evlilere göre daha fazla olduğu görülmüştür. Covid-19 ile mücadeleyi teşvik etmek için böyle bir ücretlendirmenin gerekli olduğunu düşünme oranları da bekârlarda daha fazladır. Yapılan ki-kare testinin sonuçları birlikte değerlendirildiğinde, bekâr genç erkek çalışanların Covid-19 ek ödemeleri konusunda daha fazla beklenti içerisinde oldukları ve mevcut durumdan daha fazla şikâyetçi olduklarını söylemek yerinde olacaktır.

\section{Sonuç ve Öneriler}

Sağlık hizmetlerinin sunumunda verimliliğin sağlanması, personeli teşvik etme ve hizmet kalitesinde sürekliliği sağlamak amacıyla motivasyon unsurlarının geliştirilmesi gerektiği gerçeği yok sayılamaz (SB, 2007). Bu doğrultuda, Sağlık Bakanlığı́nın Covid-19 ile mücadelede görev alan sağlık çalışanlarının performans ödemelerinin belli bir süre boyunca tavandan ödenmesi kararı, sağıık çalışanlarının sırtındaki ağır çalışma yükünü biraz da olsa hafifletmesi adına yerinde olmuştur. Ancak, Covid-19 salgınına yönelik araştırma, teşhis ve tedavi faaliyetleri kapsamında görev yapan sağlık çalışanlarına yapılan bu ek ödeme, yer ve/veya personel yönünden kapsam ve oranı ilgili sağlık kurumundaki yönetim tarafından belirlenmek kaydıyla yapılmıştır. Dolayısıyla, sağlık çalışanlarına yapılacak Covid-19 ek ödemesi ile ilgili gerek Sağlık Bakanlığı'nca yapılan yasal düzenlemenin yeterli ve adil olup olmadığı, gerekse bu ek ödemenin belirlenmesinde, dağıtımında ve ödemenin yapılmasında yasal düzenlemeler çerçevesinde takdir yetkisini kullanan sağlık kuruluşlarının ilgili yönetimlerinin bu süreci yönetirken belirlediği kriterler, izlediği yol ve kullandığı yöntemlerin sağlık çalışanlarının algı ve tutumlarını nasıl etkilediği hususu, sağlık personelinin çalışma hayatı için önemli bir hale gelmiştir. 
İçinde bulunulan pandemi sürecinde sağlık çalışanlarının performanslarının korunabilmesi ve sağlık çalışanlarına maddi yönden de destek sağlanabilmesi için, Covid-19 ek ödemeleri önemli bir konu olmuştur. Covid19 ek ödemeleri ile birlikte ödemelerin adil dağııımı konusu tartışımaya başlanmıştır. Özellikle pandemi ile birlikte sağlık çalışanlarına yönelik yaptıkları fedakârlıklar ile birlikte oluşan olumlu havanın, maddi nedenlerle dağılmaması, pandemiyle mücadelede son derece önem arz etmektedir. Bu nedenle, Covid-19 ek ödemelerinin dağııımı konusunda çalışanların fikirlerine daha fazla kulak verilmeli, ek ödeme ile ilgili alınacak yönetimsel kararlara çalışanların da katıımı sağlanmalı, adil bir ek ödeme dağııımı konusunda üst yönetim taahhüdü tam olmalı, konuyla ilgili yapılacak benzer çalışmalar desteklenmelidir.

Öte yandan, hakkaniyetli bir düzenlemeden söz edilebilmesi için sadece belirli ünvalardaki sağlık çalışanlarının değil, Covid-19 açısından hayati risk altında çalışan her personelin uygulama kapsamına alınması gerektiği konusu son derece makul ve adil bir taleptir. Illeride yapılacak yasal düzenlemelerde bu hususun göz önüne alınmasının sağlık hizmetlerinin kalitesi açısından çok önemli olduğu düşünülmektedir.

Araştırma bulgularından yola çıkarak, Covid-19 ek ödemesine yönelik sağlık çalışanlarının algı ve tutumlarına göre yapılabilecek genel bir değerlendirmede, kalite ve verimlilik ile sağlık çalışanlarının performans ve motivasyon düzeylerinin artııımasına yönelik daha tatmin edici ve genel kabul gören düzenlemelerin yapılması gerektiği, sadece dönemsel olarak iyileştirme yerine özlük hakları gibi sağlık çalışanlarının tüm hayatına dokunacak yapısal değişiklikleri içeren daha adil bir performans sisteminin getirilmesi gerektiği önerilmektedir.

\section{Kaynakça}

Adams, J.G. \& Walls, R.M. (2020). Supporting the health care workforce during the Covid-19 global epidemic. JAMA, $323(15): 1439-1440$.

Ali, S., Noreen, S., Farooq, I., Bugshan, A. \& Vohra, F. (2020). Risk assessment of healthcare workers at the frontline against COVID-19. Pak J Med Sci, 36 (COVID19-S4) : S99-S103.

Bauchner, H. \& Easley, T.J. (2020). On behalf of the entire editorial and publishing staff of JAMA And The JAMA Network. health care heroes of the COVID-19 Pandemic. JAMA, 323 (20):2021.

Chersich, M.F., Gray, G., Fairlie, L., Eichbaum, Q., Mayhew, S., Allwood, B., et al. (2020). COVID-19 in Africa: Care and protection for frontline healthcare workers. Global Health, 16 (1):46.

Choi, E., Hui, B., \& Wan, E. (2020). Depression and anxiety in Hong Kong during COVID-19. International Journal Of Environmental Research And Public Health, 17(10), 3740. https://doi.org/10.3390/ijerph17103740

Çakır, Ö. \& Sakaoğlu, H. (2014). Sağlık çalışanlarının performansa dayalı ek ödeme sisteminde ücret adaleti algısı: Tepecik Eğitim ve Araştırma Hastanesi örneği. Çalışma Ilişkileri Dergisi, 5 (1): 1- 21.

Di Tella, M., Romeo, A., Benfante, A., \& Castelli, L. (2020). Mental health of healthcare workers during the COVID-19 pandemic in Italy. Journal of Evaluation in Clinical Practice, 26(6), 1583-1587.

Erkan, A. (2011). Performansa dayalı ödeme: Sağlık Bakanlığı uygulaması. Maliye Dergisi, 160 (Ocak - Haziran): 423-438.

Farooq, I. \& Ali, S. (2020). COVID-19 Outbreak and its monetary implications for dental practices, Hospitals And Healthcare Workers. Postgrad Med J, 96 (1142): 791-792.

Fettah, K \& Şahin, B. (2009). Birinci basamak sağlık kuruluşlarında çalışan personelin performansa dayalı döner sermaye ek ödeme uygulamasına ilişkin değerlendirmeleri. Hacettepe Sağlık idaresi Dergisi, 12(2): 177-201.

Gazi, A., Tengilimoğlu, M., Top, M., Tarcan, M. \& Tekingündüz, S. (2011). Sağlık Bakanlığı hastanelerinde performansa dayalı ek ücret ödeme sisteminin değerlendirilmesi: hastaların görüşleri. Verimlilik Dergisi, (2): 97-124.

Greenberg, N., Docherty, M., Gnanapragasam, S., \& Wessely, S. (2020). Managing mental health challenges faced by healthcare workers during covid-19 pandemic. BMJ (Clinical research ed.), 368, m1211. https://doi.org/10.1136/bmj.m1211

IDA, (2021). Scale of Dental Collapse Highlighted in Survey, The Irish Dental Association. Erişim Tarihi: 23/08/2021, https://irishdentalassociation.newsweaver.com/newsletter/13ctcsav7cz1cys22xtzj2?a=1\&p=56657247\&t=22322 575 
Kablay, Y. (2014). Performansa dayalı döner sermaye primi uygulaması ve sağlık çalışanlarına etkisi. ISGUC The Journal of Industrial Relations and Human Resources, 16 (4): 85- 110.

Kaptanoglu, A. (2013). Performance based supplementary payment systems in istanbul public hospitals. Journal of Higher Education and Science, 3(2); 128-132.

Kıraç, R., Söyler, S., Yılmaz, G. \& Uyar, S. (2021). Effect of the anxiety to catch coronavirus (COVID-19) on bedtime procrastination. Cukurova Medical Journal, 46(2), 495-507.

Lai, J., Ma, S., Wang, Y., Cai, Z., Hu, J., Wei, N. et al. (2020). Factors associated with mental health outcomes among health care workers exposed to coronavirus disease 2019. JAMA Netw Open, 3 (3):e203976.

Livingston, E., Desai, A. \& Berkwits, M. (2020). Sourcing personal protective equipment during the COVID-19 pandemic. JAMA. 323(19):1912-1914. doi:10.1001/jama.2020.5317

Park S. H. (2020). Personal protective equipment for healthcare workers during the COVID-19 Pandemic. Infection \& Chemotherapy, 52(2),165-182. https://doi.org/10.3947/ic.2020.52.2.165

Rajbhandari, P. \& Maharjan, K. (2020). Willingness of emergency and medicine department doctors to work during surge of COVID-19 patients, Patan Hospital Nepal. Journal of Patan Academy of Health Sciences, 7(1), 25-30.

Rasmussen, S.A., Smulian, J.C., Lednicky, J.A., Wen, T.S. \& Jamieson, D.J. (2020). Coronavirus disease 2019 (COVID19) and pregnancy: What obstetricians need to know. Am J Obstet Gynecol, 222(5):415-426.

Saatçı E. (2020). COVID-19 Pandemisi ve sağlık çalışanları. Türkiye Aile Hekimliği Dergisi, Turkish Journal of Family Practice, 24 (4): 172-174.

Shanafelt, T., Ripp, J. \& Trockel, M. (2020). Understanding and addressing sources of anxiety among health care professionals during the COVID-19 pandemic. JAMA, 323 (21):2133- 2134.

T.C. Resmi Gazete, (2020). "Sağlık Bakanlığına Bağlı Sağlık Tesislerinde Görevli Personele Ek Ödeme Yapılmasına Dair Yönetmelikte Değişiklik Yapılmasına Dair Yönetmelik", "Yükseköğretim Kurumlarında Döner Sermaye Gelirlerinden Yapılacak Ek Ödemenin Dağıtılmasında Uygulanacak Usul Ve Esaslara Illişkin Yönetmelikte Değişiklik", 24 Mart 2020, Sayı: 31078 (Mükerrer).

T.C. Sağlık Bakanlığı (2007). Sağlıkta Performans Yönetimi Performansa Dayalı Ek Ödeme Sistemi. (Hazırlayanlar: Sabahattin AYDıN, Mehmet DEMiR) Sağlık Bakanlığı Yayını, Gözden Geçirilmiş 2. Basım, Sağlıkta Dönüşüm Serisi2, Ankara. Erişim Tarihi: 21.04.2021, https://sbu.saglik.gov.tr/Ekutuphane/Yayin/176

T.C. Sağlık Bakanlığı (2020). "COVID-19 Pandemisi Nedeniyle Sağlık Tesislerinde Ek Ödeme Yapılmasına Illişkin Usul ve Esaslar" hakkında yazı, Erişim Tarihi:23/08/2021, https://khgmekodemedb.saglik.gov.tr/Eklenti/37085/0/covid19-pandem isi-nedeniyle-ek- odeme-usul-ve-esaslaripdf.pdf?_tag1=5B606BDBE7C1C9B547350A7B2FF734 OA5826118D

Taser, M. \& Cakir, H. (2019). The effect of departmental productivity on performance-based additional pament in university hospitals: a model proposal. Research Journal of Business and Management (RJBM), 6 (4): 243-270.

Tomlin, J., Dalgleish-Warburton, B., \& Lamph, G. (2020). Psychosocial support for healthcare workers during the COVID19 pandemic. Frontiers in psychology, 11, 1960. https://doi.org/10.3389/fpsyg.2020.01960

TTD, Türk Toraks Derneği (2021). Sağlık Çalışanlarında Covıd-19 Enfeksiyonu, Aralık 2020 -Ocak 2021 Döneminde Artış Göstermiştir (Basın Bildirisi). Erişim Tarihi: 22.04.2021, Erişim adresi: https://www.toraks.org.tr/site/news/10240

Uysal, B., Demirkıran, M. \& Yorulmaz, M. (2020). Assessing of factors effecting COVID-19 mortality rate on a global basis. Turkish Studies, 15 (4):1185-1192.

Vizheh, M., Qorbani, M., Arzaghi, S.M. et al. (2020). The mental health of healthcare workers in the COVID-19 pandemic: A systematic review. J Diabetes Metab Disord 19, 1967-1978. https://doi.org/10.1007/s40200-02000643-9

WHO, World Health Organization (2020). Coronavirus Disease 2019 (COVID-19): Situation Report-51, 11/03/2020; Erişim Tarihi: 14/01/2021, Erişim adresi: https://www.who.int/ emergencies/diseases/novel-coronavirus 
WHO, World Health Organization (2021). Coronavirus Disease (COVID-19) Weekly Epidemiological Update And Weekly Operational Update, Erişim Tarihi: 14/01/2021, Erişim adresi: https://www.who.int/emergencies/diseases/novel-coronavirus-2019/situation-reports.

Yorulmaz M. \& Uysal B., (2019). Sağlıkta kalite yönetimi ve akreditasyon, Bölüm adı: (Sağlıkta Kalite Yönetim Sistemleri), Gazi Kitabevi, Editör: Umut Beylik, Keziban Avcı, Basım sayısı:1, Sayfa Sayısı 418, ISBN:978-605-344957- 7, Türkçe (Bilimsel Kitap).

Yüksel, ì. \& Sayın K. (2018). Kamu hastanelerinde performansa dayalı ek ödeme model önerisi ve örnek bir uygulama. Hukuk ve iktisat Araştırmaları Dergisi, 10 (2): 1-17.

Zhao, Y., Liang, W., Luo, Y., Chen, Y., Liang, P., Zhong, R., ... \& He, J. (2020). Personal protective equipment protecting healthcare workers in the Chinese epicentre of COVID-19. Clinical Microbiology and Infection, 26(12), 17161718. 